DOI: 10.17707/AgricultForest.62.1.35

\author{
Ljubica IVANOVIĆ, Ivana MILAŠEVIĆ, Dijana ĐUROVIĆ, \\ Ana TOPALOVIĆ,Mirko KNEŽEVIĆ, \\ Boban MUGO ̌́ A, Miroslav M. VRVIĆ
}

\title{
APPLICATION OF PLANT BIOTECHNOLOGY TECHNIQUES IN ANTIOXIDANT PRODUCTION
}

\begin{abstract}
SUMMARY
Nowadays, antioxidant compounds are receiving increased attention in scholarly literature as well as in research. Antioxidants are a diverse group of compounds that can neutralize free radicals and thus help prevent diseases that are a consequence of oxidative stress. The most common antioxidant compounds are vitamins (A-carotenoids, $\mathrm{C}$ and $\mathrm{E}$ ), thiols molecules (thioredoxins, glutathione), phenolic compounds (phenolic acids and flavonoids), enzymes and metal ions, as well as others. Plants have been shown to be an excellent source of antioxidant compounds, such as carotenoids, polyphenols, vitamins and betalains. Plant biotechnology uses the genetic engineering of agricultural crops as a means of producing foods rich in antioxidant nutrients, whilst plant cells and tissue culture techniques are used for the in vitro increment of antioxidant compounds in plant cells. There are numerous inspiring and promising reports about the possibilities of plant biotechnology that should provoke and encourage more research focused on antioxidant production from plants. The exogenous antioxidant molecules of important to human health (since endogenous antioxidants can be produced by the human cell itself) and the use of genetic engineering and plant cell culture techniques in antioxidant production in commonly used crops are presented in this paper.
\end{abstract}

Keywords: antioxidants, plant biotechnology, genetic engineering, plant tissue culture

\section{INTRODUCTION}

There has been a growing interest in the role of antioxidants in chronic diseases caused by oxidative stress. Oxidative stress is the consequence of an imbalance between free radical generation and the antioxidant protection system that leads to numerous diseases, such as Alzheimer's and Parkinson's Disease, inflammatory diseases, cardiovascular disorders and so on (Uttara et al., 2009; Hybertson et al., 2011; Djordjevic et al., 2008). ROS, reactive oxygen species,

\footnotetext{
${ }^{1}$ Ljubica Ivanović, Ivana Milašević (corresponding author: 1jivanovic7@gmail.com),BIO-ICT (Center of Excellence), Podgorica, MONTENEGRO, Dijana Đurović, Boban Mugoša, Institute of Public Health of MONTENEGRO, Ana Topalović, Mirko Knežević,Biotechnical Faculty, University of MONTENEGRO, Miroslav M. Vrvić, Faculty of Chemistry, University of BELGRADE

Notes: The authors declare that they have no conflicts of interest. Authorship Form signed online.
} 
and RNS, reactive nitrogen species, are produced in cells either through normal cell activities (e.g. through mitochondria and peroxisomes working by the action of the enzyme xanthine oxidase and so on) or in pathological states (inflammation, infections and ischemia/reperfusion injury). Also, free radicals can be generated by external factors, such as smoke from cigarettes, environmental pollutants, radiation (X, $\gamma$ and UV rays), pesticides, ozone, industrial solvents, metals and so forth (Droge, 2002; Valko et al., 2006; Valko et al., 2007). Cells are constantly exposed to free radicals, so a balance between free radical species and antioxidants is important for cell homeostasis (Figure 1). Antioxidants are synthetic or natural substances that inhibit the oxidation of other molecules by numerous mechanisms. They prevent ROS and RNS reacting with macromolecules (proteins, lipids and DNA). In cells, homeostasis is held back by the synergic activity of non-enzymatic antioxidants and the enzymes of antioxidant molecules. Antioxidants produced by human cells are called endogenous antioxidants (enzymes and proteins), whilst antioxidants taken in by food are called exogenous antioxidants, or non-enzymes antioxidants (Fang et al., 2002; Lobo et al., 2010; Kunwar et al., 2011; Yeddes et al., 2013).

The importance of exogenous antioxidant molecules for human health (since endogenous antioxidants can be produced by the human cell itself) and the use of genetic engineering and plant cell culture techniques in antioxidant production in commonly used crops are presented in this paper.

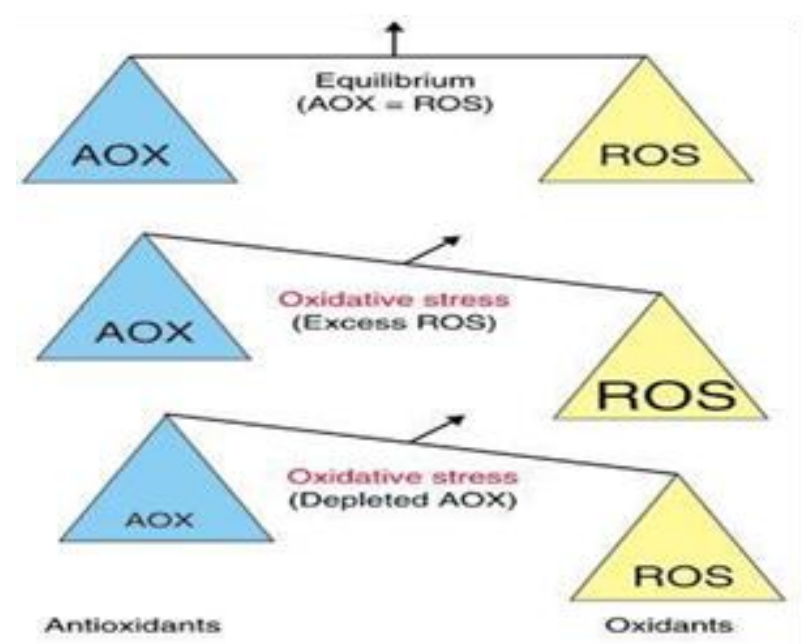

Figure 1: Equilibrium between ROS and antioxidants

\section{Genetic/Metabolic Engineering in Plants}

Food and health will always be a priority for humankind. Genetic engineering, amongst other methods, is employed for nutritional improvement of commonly used plant crops (Ryu et al., 1994; Altman et al., 2012). For this purpose, plants must have a foreign gene incorporated into them, to produce the transgenic plant Through the use of genetic techniques and metabolic 
engineering, it is possible to produce plants with desired traits (such as increased production of antioxidant compounds). This transgenic plant or GM (genetically modified) crop can be created following the most common procedure, via the Agrobacterium tumefaciens-mediated transformation method, as shown in Figure 2 (Kirakosyan et al., 2009; Madigan et al., 2006; Jhansi Rani et al., 2013).

\section{Agrobacterium tumefaciens}
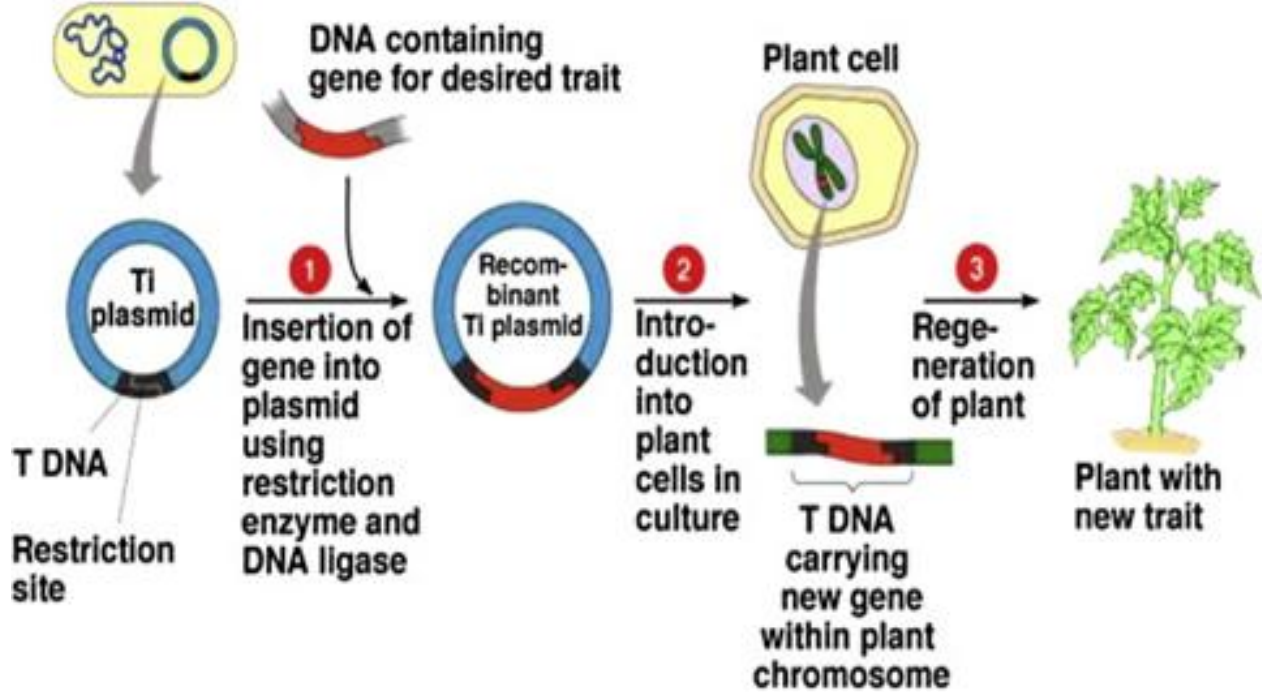

Figure 2: Process of A. Tumefaciens-mediated plant transformation

\section{Genetic/Metabolic Engineering of Flavonoid Compounds}

Flavonoids are a very diverse class of phenolic compounds that perform antioxidant activities. They consist of two aromatic rings connected by a heterocyclic ring. Their structure is also referred to as C6-C3-C6 (Figure 3). They can be subdivided into different subgroups such as flavones, flavonols, flavanones, flavanonols, flavanols, or catechins and anthocyanins. Finally, flavonoids with an open C ring are called chalcones (Ververidis et al., 2007; Madhuri et al., 1999).

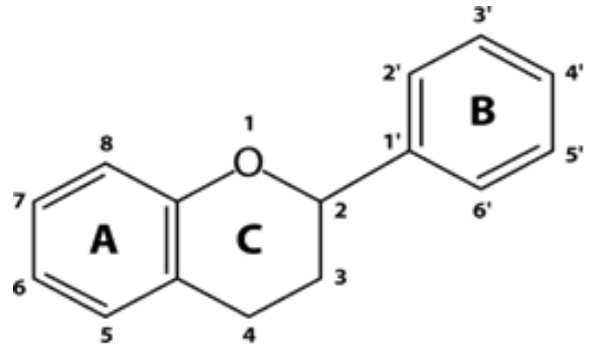

Figure 3: General structure of flavonoids 
Fruits and vegetables are the main dietary sources of flavonoids for humans, along with tea and wine. It has been shown that foods enriched with flavonoids have preventive effects on human health that are the result of their antioxidants properties. The biosynthetic pathway of flavonoid synthesis is wellknown and a simplified scheme is presented in Figure 4. Thus, it is possible to optimise genetic and regulatory processes within cells to increase the cells' production of flavonoids (Dias et al., 2014; Treutter, 2010).

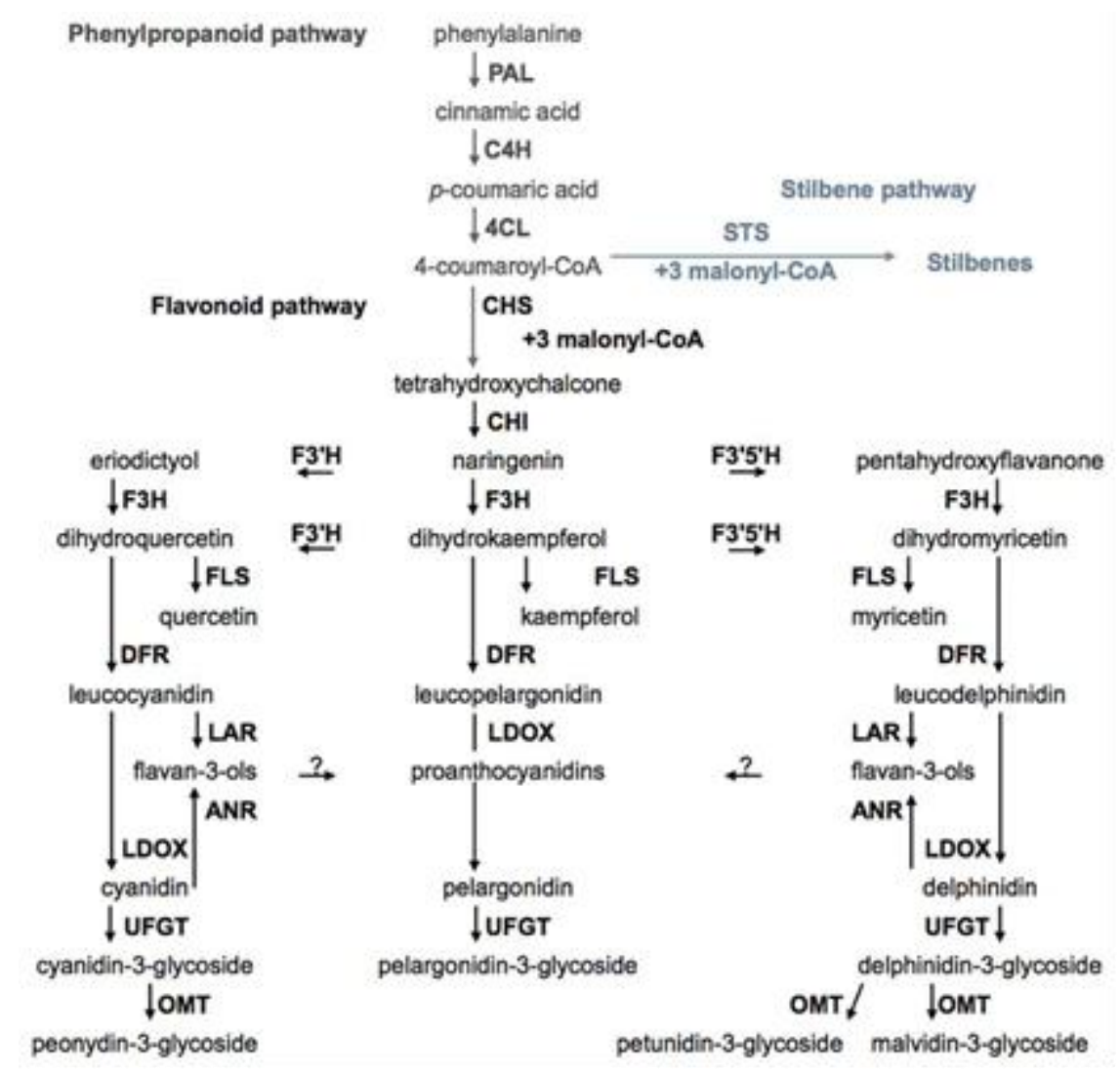

Figure 4: Biosynthetic pathways of flavonoids. Phenylalanine ammonia lyase (PAL), cinnamate-4-hydroxylase (C4H), 4-coumaroyl:CoA-ligase (4CL), stilbene synthase (STS), chalcone synthase (CHS), chalcone isomerase (CHI), flavonoid 3 '-hydroxylase $\left(\mathrm{F} 3{ }^{\prime} \mathrm{H}\right)$, flavonoid $\quad 3^{\prime}, 5^{\prime}$-hydroxylase $\quad\left(\mathrm{F}^{\prime} 5^{\prime} \mathrm{H}\right)$, flavanone-3-hydroxylase (F3H), flavonol synthase (FLS), dihydroflavonol reductase (DFR), leucoanthocyanidin reductase (LAR), anthocyanidin reductase (ANR), leucoanthocyanidin dioxygenase (LDOX), dihydroflavonol 4-reductase (DFR), flavonoid glucosyltransferase (UFGT), O-methyltransferase (OMT). 
The genetic/metabolic engineering of flavonoid compounds can be achieved through three different approaches: 1) by endogenous synthesis of flavonoids using structural and regulatory genes, 2) blocking the flavonoid pathway by the RNA interference technique and 3) the production of novel flavonoids by inserting new branches in the pathway (Bovy et al., 2007).

\section{Regulatory gene engineering}

There are two types of regulatory proteins which are important for the engineering of the flavonoid biosynthesis of regulatory genes - one from c-MYB (cell-myeloblastosis) families and the other from c-MYC (cellmyelocytomatosis) transcription factor families. Transcription factor AtMYB12 (from c-MYB families) a flavonol-specific transcriptional activator in Arabidopsis thaliana, activates a biosynthetic pathway of polyphenols, chlorogenic acid and flavonols when it is engineered in tomatoes. In GM tomatoes, the engineering of this regulatory gene directs so-called ectopic expression, which means synthesis in the tomato parts that normally do not produce any flavonoids. AtMYB12 is very promising for the improvement of polyphenol content in industrially important crops (Bovy et al., 2007; Luo et al., 2008).

Simultaneous ectopic heterologous expression of the maize transcription factor genes, LC (a member of the MYC gene families) and C1 (a member of the MYB gene families) resulted in high levels of the flavonol-kaempferol in the flesh of a transgenic tomato. However, in ripe LC/C1-transformed tomatoes, anthocyanins were not detected (though in the leaves, anthocyanins were present), probably due to insufficient expression of the gene that codes for flavanone-3',5'-hydroxylase (required for the modification of the B ring) and a greater affinity of the dihydroflavonol reductase for the substrate dihydromyricetin (Bovy et al., 2007; Bovy et al., 2002). The anthocyanins content of the transgenic tomato could be increased by overexpression of ANT1 transcriptional factors. The ANT1 gene encodes a MYB-factor protein (c-MYB families) and regulates a variety of genes involved in anthocyanin accumulation (Mathews et al., 2003; Buteli et al., 2008; Sangera et al., 2013).

\section{Engineering of structural genes}

In the tomato's peel, it is possible to detect following flavonoids: naringeninchalcone, quercetin-rutinoside (rutin) and quercetin-3-trisaccharide, but the tomato flesh shows very low expression levels for flavonoids in general. This is because the activity of the endogenous flavonoid biosynthetic genes chalcone synthase (chs), chalcone isomerase (chi) and flavonol synthase (fls). Transcripts were undetectable in the fruit flesh. The chi (chalcon isomease) gene from Petunia was introduced in the tomato and its overexpression resulted in elevated levels of flavonols up to 70-fold of quercetin glycosides and smaller, but still substantial, increases in kaempferol glycosides in the fruit peel. The flavonoid level in tomato flesh can be incremented using four flavonoid 
biosynthetic genes from Petunia (CHS, CHI, F3H and FLS). When these genes were assembled in the tomato, the flavonoid production was increased in both the peel (primarily quercetin glycosides) and the flesh (primarily kaempferol glycosides). Interestingly, when expressed separately, none of these four genes was sufficient to lead to flavonol production in the fruit flesh, so the metabolic complex comprising of CHS, CHI, F3H and FLS in tomato flesh plays a key role (Muir et al., 2001; Bovy et al., 2007).

The introduction of two structural genes into the tomato - the naringenin8-dimethilally-transferase (N8DT) gene and chalcone isomerase (CHI) gene and their overexpression lead to accumulated rutin compared to wild-type tomatoes (Kawasaki et al., 2014). It is possible to gain up to a 78-fold increase in total fruit flavonols through ectopic expression of a single structural gene $\mathrm{CHI}$ (Verhoeyen at al., 2002).

\section{Blocking specific steps in flavonoid biosynthesis using the RNA interference technique}

This approach uses the RNA molecule which is complementary with the RNA transcripts of some genes and commonly important in flavonoid biosynthetic pathways. This antisense RNA is called RNA interference (RNAi). In tomatoes, when the CHS1 gene (encode for the first enzyme in flavonoid synthesis - chalcone synthase) was inhibited, the result was decreased activity of chalcone synthase and the total flavonoid level (naringenin chalcone and quercetin rutinoside)was reduced relative to the wild-type. The flavonol level was decreased after introducing a FLS (flavonol synthase) iRNA construct, but it was detected as anthocyanins accumulation due to low activity of the FLS and DFR (dihydroflavanol 4-reductase) enzymes. RNAi used for the F3H (flavanone 3 -hydroxylase) gene showed a decrease of $20 \%$ as compared to the wild type. The DET1 (De-etiolated1) regulatory gene was inhibited using RNAi technology and the result was an increased level of flavonoids ( $\beta$ carotene and lycopene) (Casacuberta et al., 2015; Schijlen et al., 2007; Bovy et al., 2007; Davaluri et al., 2005).

\section{Introducing novel branches in flavonoid biosynthetic pathways (stilbenes and isoflavon production)}

Stilbenes are phenolic compounds with antioxidant properties and transreverstatol is such a compound. The key enzyme in reverstatol synthesis is stilbene synthase (StSy), but generally plants do not have StSy because they do not have any StSy genes (Treutter et al., 2010), so the production of revarstatol might be achieved if StSy genes could be incorporated into crops. The StSy gene was engineered from the grape to the tomato which resulted in reverstatol and its derivate production. By this genetic manipulation, the content of other phenolic compounds (such as naringenin and chlorogenic acid) in the tomato was not changed. Also, the StSy gene from Parthenoc issushenryana was introduced into 
lettuce which resulted in the synthesis of revarstatol in transgenic lettuce (Bovy et al., 2007; Giovinazzo et al., 2005; Schijlen et al., 2006; Liu et al., 2006).

Soybean isoflavon synthase genes have also been engineered in the popular crop tomato which lead to isoflavon production in transgenic tomatoes without any side effects on the endogenous phenolic content (Shih et al., 2008; Bovy et al., 2007).

\section{Genetic/metabolic engineering of carotenoids}

Carotenoids or tetratepenoids are yellow, orange and red organic pigments synthesised by plants. Some of them, such as $\alpha$-carotene, $\beta$-carotena and $\beta$ cryptoxanthin, are provitamin A carotenoids which means they can be converted by the body to retinol (vitamin A). Lutein, zeaxantin and lycopene have no vitamin A activity. Carotenoids are important antioxidant molecules in a lipid environment, along with $\alpha$ tocopherol, and, because of this, they are important ingredients in the human diet (Eldahshan et al., 2013; www.scielo.cl/scielo.php?pid=S0718-16202009000200001\&script=sci_arttext). In order to increase the levels of nutritionally relevant carotenoids in crop plants, it is important to understand biosynthetic pathways and the regulation of this process so different strategies can be employed. Carotenoid biosynthesis and its related pathways are shown in Figure 5.

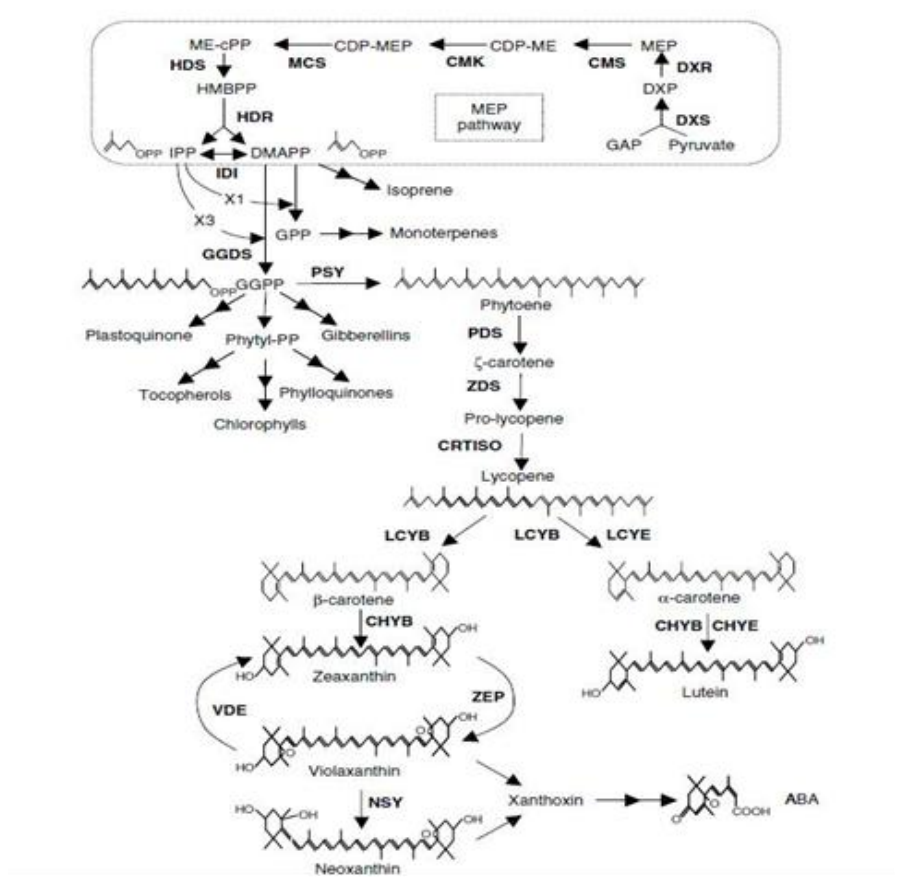

Figure 5: Carotenoid biosynthesis and related pathways in plants. GAP, glyceraldehyde 3-phosphate; DXP, deoxyxylulose 5-phosphate; MEP, methylerythritol4-phosphate; 
CDP-ME, 4-diphosphocytidyl-methylerythritol; CDP-MEP, 4-diphosphocytidylmethylerythritol 2-phosphate; ME-cPP, methylerythritol2,4-cyclodiphosphate; HMBPP, hydroxymethylbutenyl 4-diphosphate; IPP, isopentenyldiphosphate; DMAPP, dimethylallyldiphosphate; GPP, geranyldiphosphate; GGPP, geranylgeranyldiphosphate; ABA, abscisic acid. Enzymes are indicated in bold: DXS, DXP synthase; DXR, DXPreductoisomerase; CMS, CDP-ME synthase; CMK, CDP-ME kinase; MCS, MEcPP synthase; HDS, HMBPP synthase; HDR, HMBPP reductase; IDI, IPPisomerase; GGDS, GGPP synthase; PSY, phytoene synthase; PDS, phytoenedesaturase; ZDS, zcarotene desaturase; CRTISO, carotenoid isomerase; LCYB, lycopene b-cyclase; LCYE, lycopene e-cyclase; CHYB, carotenoid b-ring hydroxylase; CHYE, carotenoid e-ring hydroxylase; ZEP, zeaxanthinepoxidase; VDE, violaxanthin de-epoxidase; NSY, neoxanthin synthase.

Metabolic engineering, along with genetic engineering of structural genes, are mainly used for the increment of carotenoid products. The structural gene, crtB (phytoene synthase is product of this gene), which is isolated from Erwinia uredovora, has been overexpressed in the transgenic tomato. The result was total carotenoid content increment up to 2.4 times as compared to the control. The obtained transgenic tomato is suitable for the production of processed products (Fraser et al., 2002; Giuliano et al., 2008). Since lycopene and other carotenoids are hydrophobic, its absorption in the body is low which means low bioavailability. Tomato processing, which includes the addition of fat, increases bioavailability and thus the function of these compounds (Richelle et al., 2002). To increase carotenoid content in plant crops, structural genes are mainly used, such as a crtB (isolated from) gene, whose product is a key enzyme in the biosynthetic pathway of carotenoids. When the crtB gene is overexpressed in the transgenic tomato, theripe tomato fruit contains significant amounts of lycopene, while oxidised carotenoids (xanthophylls) are present only in trace amounts. The engineering of the structural genes of lycopene $\beta$-cyclase (LCY-b, from Arabidopsis) and $\beta$-carotene hydroxylase (b-chy from pepper) resulted in the increase of $\beta$-carotene, $\beta$-cryptoxanthin and zeaxanthin in the transgenic fruit. A change in carotenoid composition could be detected by the naked eye because the transgenic fruit, compared to the control, changed colour from red to yellow. The transformed lines demonstrated unchanged levels of expression of the endogenous biosynthetic genes of carotenoids which tells us that the production of carotenoids is the result of the expression of the introduced genes and not due to deregulation of the endogenous genes (Dharmapuria et al., 2002; Giuliano et al., 2008).The approach by which structural genes are silenced by RNAi strategy in order to increase the content of carotenoids was achieved in potatoes. A potato contains low levels of carotenoids - mainly lutein and violaxanthin (that have no vitamin A activity). Because the potato is a widely used crop across the world, research was performed which managed to increase the level of $\beta$-carotene by 38 times and incremented the total level of the carotenoids by 4.5 times by blocking the CHY 1 and CHY 2 genes. CHY 1 and CHY 2 genes code for the enzyme $\beta$ carotene hydroxylase which is, along with the $\varepsilon$ cyclisation of lycopene, a key 
regulatory step in the carotenogenesis of potatoes. Silencing $\beta$-carotene hydroxylase increases total carotenoid and $\beta$-carotene levels in potatoes (Diretto et al., 2007; Giuliano et al., 2008; Apel et al., 2009).

Table 1: List of genetically engineered crops with enhanced carotenoid/flavonoid content

\begin{tabular}{|c|c|c|}
\hline $\begin{array}{l}\text { GM } \\
\text { product }\end{array}$ & Nutrient & Gene introduced \\
\hline Tomato & $\begin{array}{l}\beta \text {-carotene } \\
\text { Lutein } \\
\text { Anthocyanin } \\
\beta \text {-cryptoxanthin, zeaxanthin } \\
\text { Lycopene } \\
\text { Phytoene } \\
\text { isoflavone/genistin } \\
\text { Stilbenes } \\
\text { Flavonoid/quercetin kaempferol } \\
\text { Flavonoid } \\
\text { Flavonol }\end{array}$ & $\begin{array}{l}\text { BLcy/Arabidopsis }+\beta \text { Chy/Pepper } \\
\text { DET1/Tomato (RNAi) } \\
\beta \text {-Lcy/Arabidopsis } \\
\text { CRY2/Tomato } \\
\text { Del/Snapdragon+Ros1/Snapdragon } \\
\text { B-Lcy/Arabidopsis+ } \beta \text { Chy/Pepper } \\
\text { ySAMDC, Spe2/Yeast } \\
\text { CrtB/E. uredovore } \\
\text { GmIFS2/Soybean } \\
\text { STS/Vitisvinifera } \\
\text { CHI/Petunia } \\
\text { DET1/Tomato (RNAi) } \\
\text { MYB12/Arabidopsis }\end{array}$ \\
\hline Potato & $\begin{array}{l}\text { Carotenoid } \\
\text { Carotenoids } \\
\beta \text {-carotene: carotenoids }\end{array}$ & $\begin{array}{l}\text { Or/cauliflower } \\
\text { CrtI, CrtBandCrtY/E. uredovora } \\
L C Y \text {-e/potato (antisense) }\end{array}$ \\
\hline Brassica & $\begin{array}{l}\beta \text {-carotene, Lutein } \\
\text { Carotenoid } \\
\beta \text {-carotene }\end{array}$ & $\begin{array}{l}\varepsilon-C Y C / \text { Brassica napus(RNAi) } \\
\text { crtB/bacteria } \\
\text { crtI }+ \text { crtb/bacteria } \\
\text { DET1 (RNAi suppression) }\end{array}$ \\
\hline Canola & Carotenoid & $\begin{array}{l}i d i+c r t W+c r t Z(\text { synthetic }) / \text { marine bacteria } \\
+c r t E+c r t B+c r t I \\
+c r t Y / \text { Pantoeaananatis }\end{array}$ \\
\hline Flax & Carotenoid & crtB/P. ananatis \\
\hline Carrot & Ketocarotenoid & CrtO/Haematococcuspluvialis \\
\hline Lettuce & Resveratrol & STS/Parthenocissushenryana \\
\hline Apple & trans-piceid & Vst $1 / V$. vinifera \\
\hline Kiwi & Piceid & Stibene synthase/Vitis spp \\
\hline Papaya & Piceid & Vst1/V. vinifera \\
\hline Strawberry & $\begin{array}{l}p \text {-coumaryl alcohol, } p \text {-coumaryl-1- } \\
\text { Acetate }\end{array}$ & CHS/strawberry (antisense) \\
\hline
\end{tabular}


The engineering of regulatory genes for carotenoid amelioration is not well-developed in the case of flavonoids because the transcription factors that control the synthesis of isoprenoid compounds are not known.

However, researchers managed to isolate the regulatory Or gene from cauliflower and incorporate it into potatoes and thus to increase by six times the content of carotenoids in the transgenic potatoes. Besides this, the introduction of this gene leads to the differentiation of plastids hromoplaste and facilitated the identification of key steps in the biosynthesis of carotenoids. The Or gene product is a protein, DnaJ which contains a cysteine-rich domain. It is interesting that the DnaJ transcription factor does not increase the level of carotenoids by stimulating endogenous biosynthesis, but by affecting the formation of isolated structures within the hromoplast in which carotenoids have been accumulated (Lu et al., 2006; Lopez et al., 2008; Sanghera et al., 2013).

In tomatoes, the regulatory gene DET1 (TDET1) has been suppressed using fruit specific promoters, combined with RNA interference (RNAi) technology. Repression of this regulatory gene increases the level of carotenoids. Such transgenic tomato plants show that both lycopene and $\beta$ carotene were generated at higher levels than in wild-type fruit with no negative effects on fruit yield and quality (Davaluri et al., 2005).

It is interesting to mention the approach by which the final product (in this case, carotenoid compounds) is elevated by increasing the supply of precursors in the biosynthetic pathway. The increase in carotenoids (phytoene and carotene) is achieved by increasing the precursor 1-deoxy-D-xylose-5-phosphate (DXP) which was synthesised from pyruvate and glyceraldehyde-3-phosphatein in the MEP pathway by DXP synthase enzymes. The DXP synthase was isolated from bacteria and introduced by engineering into the tomato (see Figure 5) (Enffisi et al., 2005).

The list of genetically engineered crops with enhanced carotenoid/flavonoid content is shown in Table 1 (Sanghera et al., 2013).

\section{Plant tissue culture}

Many years ago, it was thought that plant cells could not compete with microorganism cells in terms of the production of important metabolites due to the low rate of multiplication of plant cells. However, the production of secondary metabolites unique to plants demands the use of plant cell cultures, so different types of plant tissue cultures were used, both for commercial herbal products and in basic plant research. In plants, many somatic cells are totipotent, meaning that they contain all genes capable of being expressed by the plant and they can develop into the whole plant under the appropriate conditions. To create a successful culture of plant cells, tissues and organs, it is necessary to use the appropriate plant-starting material which is usually an explant, a small fraction of an intact plant taken under sterile conditions. The culture of plant cells, tissues or organs can be used for production of antioxidant compounds under strictly controlled conditions (Matkowski et al., 2008; Moscatiello et al., 2013; Orhan, 
2012;http://www.researchgate.net/publication/51077608_Plant_cell_cultures_bio reactors_for_industri al_production, 2009).

Strategies for increased antioxidant production by plant tissue culture

The following factors are important for the optimisation of antioxidant production in plant tissue culture:

- Optimisation of biosynthesis by culture conditions - environmental and nutritional factors influence the biosynthetic pathways of secondary metabolites. The media composition has to be optimised for both an intensive biomass increase and the accumulation of the desired metabolite.

- Determining whether the desired metabolite is produced in greater quantities in differentiated or undifferentiated cells.

- Selection of high-producing cell lines with a selecting agent.

- Precursor feeding and biotransformation - the absence of the precursor in the culture may be due to insufficient expression of the gene involved in the synthesis of the metabolites due to the absence of the stimulus in the environment.

- Elicitation and stress-induced production.

- Transformation with Agrobacterium rhizogenes-hairy roots. A number of species have been transformed with A. rhizogenes in order to achieve transformed root induction.

Now we will present some antioxidant compounds that are produced from in vitro cultures (Matkowski et al., 2008; Ryu et al., 1994; Altman et al., 2012).

\section{Production of phenolic acid by plant tissue culture}

Rosmarinic acid, a phenolic compound and a two caffeic acid molecule, is very important for medicine and pharmacology. Rosmarinic acid has been produced from cell suspension culture, callus culture and from the transformed roots of different species (see Table 2). Since it has been shown that two effective methods to improve the accumulation of secondary metabolites in plant cell cultures are precursor feeding or elicitor treatment, researchers managed to produce rosmarinic acid by Lavandula vera MM cell suspension culture using vanadyl-sulfate as an abiotic elicitor. Rosmarinic acid production was increased by up to $3.92 \mathrm{~g} / \mathrm{L}$ ( 2.8 times higher as compared to the control cultivation) and it was observed that the extracellular content of this molecule was 3.3 times higher when compared to the control variant, whilst the intracellular content represented no significant amount in the culture medium (Matkowski et al., 2008; Georgiev et al., 2006; Georgiev et al., 2006).

Cynarine and chlorogenic acid are phenolic antioxidant compounds with antimicrobial activities. An experiment produced cynarine and chlorogenic acid from calluses (calluses were obtained from disks of young cardoon leaves) and from leaves of Cynara cardunculus var. cardunculus, and the calluses gave a higher content of cynarine than the in vivo leaves, so in vitro tissue cultures can be used as a source to obtain cynarine for pharmaceutical purposes. However, the 
antioxidant properties of the in vivo leaves showed higher activity than the calluses, probably because leaves contain other phenolic compounds which increased the antioxidant activity of the in vivo leaves (Trajtemberg et al., 2006; Siahpoush et al., 2011; Matkowski et al., 2008).

\section{Flavonoid production by plant tissue culture}

Flavonoids can be produced by using callus cultures, cell suspension cultures and/or organ cultures. Amongst flavonoids, flavone C-glycosides are very important therapeutic molecules for disorders related to oxidative stress. Flavone C-glycosides are rare in plants, but they can be produced by callus cultures of Passiflora quadrangularis. The level of the flavones orientin, isoorientin, vitexin and isovitexin is increased when a callus is treated with UV-B irradiation. The antioxidant activities of the treated callus is higher by about $50 \%$ when compared to the untreated calluses (Matkowski et al., 2008; Antognoni et al., 2007).

Rutin, from the flavon group of flavonoids, was produced from hairy root cultures of buckwheat (Fagopyrum esculentum). Researchers examined the effect of different media and the effect of the plant hormone, auxin, on rutin production and it was concluded that hairy root cultures are a good alternative approach for rutin production (Lee et al., 2007).Anthocyanins were also obtained from selected callus cultures of Ajuga reptans and from a cell suspension culture which could only be established in a light-dark cycle. Also, anthocyanins can be produced from Glehnia littoralis and Ipomoea batatas by using callus and cell suspension cultures (Callebaut et al., 1990, Terehara et al., 2001).

It was found that $\mathrm{C}$. roseus anthocyanin biosynthetic enzymes are expressed both in vivo and in vitro. This was concluded after a comparison was made between anthocyanin production in stable cell suspension lines of Catharanthus roseus and from flowers obtained both from somatic embryogenesis and field-grown plants. The anthocyanin content was 1.5 times higher in the flowers from both plant types than that obtained from cell suspensions (Matkowski et al., 2008: Filippini et al., 2003).

\section{Carotenoid production by plant tissue culture}

Carotenoids production was achieved from calluses of Tagets erecta's yellow and white flowers. For this purpose, the callus was treated with $9 \mu \mathrm{M} 4$ dichlorophenoxyacetic acid (2,4-D) and $8 \mu \mathrm{M}$ benzyladenine (BA). From the yellow flower callus, the main carotenoids were lutein and zeaxanthin, whereas the white flower callus gave lutein, zeaxanthin, $\beta$-cryptoxanthine and $\beta$-carotene. It can be concluded that the white callus of Tagets erecta could be used as a good source of different carotenoids ( Benítez-García, I. et al., 2014).

\section{Betalains}

Betalains are nitrogen containing compound pigments widely used as nontoxic food colourants. There are two classes of betalains - betaxantins and betacyanins. Betalains show high biological value and, in vitro simulation of 
gastrointestinal conditions, their radical scavenging activity decreased from $75 \%$ inhibition of DPPH (2,2-diphenyl-1-pycril-hydrazil) to about 38\%. These results open up possibilities for the use of betalains as additives in different food systems. The biosynthesis of betalains is poorly known, so genetic engineering is not applicable yet. On the other hand, betalain has been produced from the hairy root culture of Beta vulgaris L (red beetroot). The suitable technique for cultivation of hairy roots is immersion which has previously been implemented and the result was $18.8 \mathrm{mg} / \mathrm{g}$ dry biomass (DB) and betalains $(9.6 \mathrm{mg} / \mathrm{g} \mathrm{DB}$ betacyanins and $9.2 \mathrm{mg} / \mathrm{g} \mathrm{DB}$ betaxanthins) (Yeddes et al., 2013; Clifford et al., 2015; Pavlov et al., 2006).

Some selected examples of the production of antioxidants from different plant culture systems are shown in Table 2:

Table 2: Selected examples of the production of antioxidants from different plant culture systems

\begin{tabular}{|l|l|l|}
\hline Species & Compounds & Culture system \\
\hline Ajuga reptans & Anthocyanins & Flower cell culture \\
\hline Anchusa officinalis & Rosmarinic acid & Cell suspension \\
\hline Anthoceros agrestis & Rosmarinic acid and its glucosides & Cell suspension \\
\hline Arachis hypogea & Piceatannol (a stilbene) & Callus \\
\hline Artemisia judaica & Flavonoids & Shoot cultures in bioreactor \\
\hline Beta vulgaris & Betalains & Cell suspension, hairy roots \\
\hline Carthamus tinctorius & Kinobeon A & Cell suspension \\
\hline Cistanche deserticola & Phenylethanoid glycosides & Cell suspension \\
\hline Cynara cardunculus & Cynarin, chlorogenic acid & Callus \\
\hline Daucus carota & Anthocyanins & Callus, cell suspensions \\
\hline Fagopyrum esculentum & Rutin & Hairy roots \\
\hline Glehnia littoralis & Anthocyanins & Callus, cell suspension \\
\hline Hemidesmus indicus & Rutin & Callus, shoot culture \\
\hline Hyssopus officinalis & Rosmarinic acid, lithospermic acid B & Hairy roots \\
\hline Ipomoea batatas & Anthocyanins & Callus, cell suspension \\
\hline Lavandula officinalis & Rosmarinic acid & $\begin{array}{l}\text { Callus, cell suspension, } \\
\text { bioreactor }\end{array}$ \\
\hline Ocimum basilicum & Rosmarinic acid & $\begin{array}{l}\text { Bioreactor culture of nodal } \\
\text { explants and cell suspension }\end{array}$ \\
\hline $\begin{array}{l}\text { Passiflora } \\
\text { quadrangularis }\end{array}$ & Flavone-C-glycosides & UV irradiated callus \\
\hline Petroselinum sativum & Flavonols and flavones & Cell suspension \\
\hline Stevia rebaudiana & Flavonoids & Callus \\
\hline Vaccinium pahalae & Anthocyanins & $\begin{array}{l}\text { Cell and aggregate } \\
\text { suspension }\end{array}$ \\
\hline Vitis vinifera & Stilbenes, procyanidins & Cell suspension \\
\hline
\end{tabular}




\section{CONCLUSIONS}

Antioxidant compounds, such as carotenoids and flavonoids, are present in fruits and vegetables. The enrichments of antioxidants in agricultural products are achieved through genetic engineering and breeding transgenic crops. On the other hand, some antioxidant compounds can be produced for therapeutic application using the methodology of plant cell culture (callus, cell suspensions, tissue/organ culture and so on). The concept of functional food gives us the opportunity to research the possibilities of genetic engineering techniques and the methodology of plant cell cultures and to take this work in desired directions.

\section{ACKNOWLEDGEMENTS}

This work has been supported by the Ministry of Science of Montenegro and the HERIC project through the BIO-ICT Centre of Excellence (Contract No. 01-1001).

\section{REFERENCES}

Aharoni, A. \& Galili, G. (2011): Metabolic engineering of the plant primary-secondary metabolism interface. Current Opinion in Biotechnology, 22: 239-244.

Altman A. \& Hasegawa P.M. (2012): Plant biotechnology and agriculture. Elsevier Inc. ISBN: 978-0-12-381466-1.

Antognoni, F., Zheng, S., Pagnucco, C., Baraldi, R., Poli F. \& Biondi S. (2007): Induction of flavonoid production by UV-B radiation in Passiflora quadrangularis callus cultures. Fitoterapia, 78: 345-52.

Apel, W. \& Bock, R. (2009): Enhancement of Carotenoid Biosynthesis in transplastomic tomatoes by induced lycopene-to-provitamin a conversion. Plant Physiology, 151 (1): 59-66.

Benítez-García, I., Vanegas-Espinoza, P. E., Meléndez-Martínez, A.J., Heredia, F. J., Paredes-López, O. \& Villar-Martínez, A. A. Del (2014): Callus culture development of two varieties of Tagetes erectaand carotenoid production. Electronic Journal of Biotechnology, 17: 107-113.

Bovy, A., Schijlen, E. \& Hall, R.D. (2007): Metabolic engineering of flavonoids in tomato (Solanum lycopersicum): the potential for metabolomics. Metabolomics, 3: 399-412.

Bovy, A., Vos, R., Kemper, M., Schijlen, E. \& Pertejo, M.A. (2002): High-flavonol tomatoes resulting from the heterologous expression of the maize transcription factor genes LC and C1. The Plant Cell, 14 (10): 2509-2526.

Butelli, E., Titta, L., Giorgio, M., Mock, H.P., Matros, A., Peterek, S., Schijlen, E.G.W.M., Hall, R.D, Bovy, A.G., Luo, J. \& Martin, C. (2008): Enrichment of tomato fruit with health-promoting anthocyanins by expression of select transcription factors. Nature biotechnology, 26 (11).

Callebaut, A., Hendrickx G., Voets, A.M. \& Motte, J.C. (1990): Anthocyanins in cell cultures of Ajuga reptans. Phytochemistry, 29: 2153-8.

Casacuberta, J.M., Devos, Y., Jardin, P., Ramon, M., Vaucheret H., \& Nogue, F. (2015): Biotechnological uses of RNAi in plants: risk assessment considerations. Trends in Biotechnology, 33 (3).

Clifford, T., Howatson, G., Wes,t D.J. \& Stevenson, E.J. (2015): The potential benefits of red beetroot supplementation in health and disease. Nutrients, 7: 2801-2822. 
Davuluri, G.R., Tuinen, A. van, Fraser, P.D, Manfredonia, A., Newman, R., Burgess, D., Brummell, D.A., King, S.R., Palys, J., Uhlig, J., Bramley, P.M., Pennings, H.M.J. \& Bowler, C. (2005): Fruit-specific RNAi-mediated suppression of DET1enhances carotenoid and flavonoid content in tomatoes. Nature biotechnology, 23 (7).

Dias, J. S. \& Ortiz, R. (2014): Advances in transgenic vegetable and fruit breeding. Agricultural Sciences, 5: 1448-1467.

Diretto, G., Welsch, R., Tavazza, R., Mourgues, F., Pizzichini, D. \& Beyer, P. (2007): Silencing of $\beta$-carotene hydroxylase increases total carotenoid and beta-carotene levels in potato tubers. BMC Plant Biology, 7: 11-18.

Djordjević, V.B., Zvezdanović L. \& Cosić V. (2008): Oxidative stress in human diseases. Srp.Arh.Celok.Lek., 136 ( $\sup 2$ ): 158-65.

Dharmapuria, S., Rosati, C., Pallaraa, P., Aquilania, R., Bouvier, F., Camara, B. \& Giuliano, G. (2002): Metabolic engineering of xanthophyll content in tomato fruits. FEBS Letters, 519: 30-34.

Droge, W. (2002): Free Radicals in the Physiological Control of Cell Function. Physiol. Rev., 82: 47-95.

Eldahshan, O.A. \& Singab, A.N.B. (2013): Carotenoids. Journal of Pharmacognosy and Phytochemistry, 2 (1): 225-234.

Enfissi, E.M.A., Fraser, P.D., Lois, L.M., Boronat, A., Schuch, W. \& Bramley, P.M. (2005): Metabolic engineering of the mevalonate and nonmevalonate- isopentenyl diphosphate-forming pathways for the production of health-promoting isoprenoids in tomato. Plant Biotechnology Journal, 3: 17-27.

Fang, Y.Z., Yang, S. \& Wu, G. (2002): Free radicals, Antioxidants, and Nutrition. Nutrition, 18: 872-879.

Filippini, R., Caniato, R., Piovan, A. \& Cappelletti, E.M. (2003): Production of anthocyanins by Carthamus tinctorius. Fitoterapia, 74: 62-7.

Fraser, P.D., Romer, S., Shipton, C.A., Mills, P.B., Kiano, J.W., Misawa, N., Drake, R.G., Schuch, W. \& Bramley, P.M. (2002): Evaluation of transgenic tomato plants expressing an additional phytoene synthase in a fruit-specific manner. PNAS, 99(2): 1092-1097.

Giovinazzo, G., D’Amico, L., Paradiso, A., Bollini, R., Sparvoli, F. \& DeGara, L. (2005): Antioxidant metabolite profiles in tomato fruit constitutively expressing the grapevine stilbene synthase gene. Plant Biotechnology Journal, 3: 57-69.

Giuliano, G., Tavazza, R., Diretto, G., Beyerand, P. \& Taylor, M.A. (2008): Metabolic engineering of carotenoid biosynthesis in plants. Trends in Biotechnology, 26(3).

Georgiev, M., Kuzeva, S., Pavlov, A., Kovacheva, E. \& Ilieva, M. (2006): Enhanced rosmarinic acid production by Lavandula vera MM cell suspension culture through elicitation with vanadyl sulfate. Z. Naturforsch, 61: 241-4.

Georgiev, M., Pavlov, A. \& Ilieva, M. (2006): Selection of rosmarinic acid producing Lavandula vera MM cell lines. Process. Biochem., 41: 2068-71.

Hybertson, B.M., Gao, B., Bose, S.K. \& McCord, J.M. (2011): Oxidative stress in health and disease: The therapeutic potential of Nrf2 activation. Molecular aspects of medicine, 32 (4-6): 234-246.

Jhansi Rani S. \& Usha R. (2013): Transgenic plants: Types, benefits, public concerns and future. Journal of Pharmacy Research, 6: 879-883.

Kawasaki, T., Koeduka, T., Sugiyama, A., Sasaki, K., Linley, P.J., Shitan, N., Kumano, T., Yamamoto, H., Ezura, H., Kuzuyama, T. \& Yazaki, K. (2014): Metabolic 
engineering of flavonoids with prenyl transferase and chalcone isomerase genes in tomato fruits. Plant biotechnology.

Kunwar, A. \& Priyadarsini, K.I. (2011): Free radicals, oxidative stress and importance of antioxidants in human health. J. Med. Allied. Sci., 1(2): 53-60.

Lee, S.Y., Cho, S.I., Park, M.H., Kim, Y.K., Choi, J.E. \& Park, S.U. (2007): Growth and rutin production in hairy root cultures of buckwheat (Fagopyrum esculentum). Prep. Biochem. Biotechnol., 37: 239-46.

Liu, S., Hu, Y., Wang, X., Zhong, J. \& Lin, Z. (2006): High content of resveratrol in lettuce transformed with a stilbene synthase gene of Parthenocissus henryana. Journal of Agricultural and Food Chemistry, 54: 8082-8085.

Lobo, V., Patil, A., Phatak, A. \& Chandra, N. (2010): Free radicals, antioxidants and functional foods: Impact on human health. Pharmacogn. Rev., 4 (8): 118-126.

Lopez, A.B., Van Eck, J., Conlin, B.J., Paolillo, D.J., O’Neill, J. \& Li, L. (2008): Effect of the cauliflower OR transgene on carotenoid accumulation and chromoplast formation in transgenic potato tubers. Journal of Experimental Botany, 59: 213223.

Lu, S., Van Eck, J., Zhou, X., Lopez, A.B., O’Halloran, D.M. \& Cosman, K.M. (2006): The cauliflower Or gene encodes a DnaJ cysteine-rich domain-containing protein that mediates high levels of b-carotene accumulation. Plant Cell, 18: 3594-3605.

Luo, J., Butelli, E., Hill, L., Parr, A., Niggeweg, R. \& Bailey, P. (2008): AtMBY12 regulates caffeoyl quinic acid and flavonol synthesis in tomato: expression in fruits results in very high levels of both types of polyphenol. Plant Journal, 56: 316-326.

Madigan, M.T., Martinko, J.M., Dunlap, P.V. \& Clark, D.P. (2006): Brock Biology of Microorganisms. Pearson Education, Inc., pp 268-271; 970-992. 11th edition, 992 pp.

Madhuri, G. \& Reddy, A. R. (1999): Plant biotechnology of flavonoids. Plant biotechnology, 16 (3): 179-199.

Mathews, H., Clendennen, S.K., Caldwell, C.G., Liu, X.L., Connors, K., Matheis, N., Schuster, D.K., Menasco, D.J., Wagoner, W., Lightner, J. \& Wagner, D.R. (2003): Activation tagging in tomato identifies a transcriptional regulator of anthocyanin biosynthesis, modification, and transport. The Plant Cell, 15(8): 1689-1703.

Matkowski, A. (2008): Plant in vitro culture for the production of antioxidants - A review. Biotechnology Advances, 26: 548-560.

Moscatiello, R., Baldan, B. \& Navazio, L. (2013): Plant cell suspension cultures. Methods Mol. Biol., 953: 77-93.

Muir, S.R., Collins, G.J., Robinson, S., Hughes, S., Bovy, A. \& De Vos, C.H.R. (2001): Overexpression of petunia chalcone isomerase in tomato results in fruit containing increased levels of flavonols. Nature Biotechnology, 19: 470-474.

Orhan, I. (2012): Biotechnological production of plant secondary metabolites. e-ISBN: 978-1-60805-114-4.

Pavlov, A. \& Bley, T. (2006): Betalains biosynthesis by Beta vulgaris L. hairy root culture in a temporary immersion cultivation system. Process Biochemistry, 41: $848-852$.

Richelle, M., Bortlik, K., Liardet, S., Hager, C., Lambelet, P., Baur, M., Applegate, L.A. \& Offord, E.A. (2001): A food-based formulation provides lycopene with the same bioavailabilityto humans as that from tomato paste. Human Nutrition and Metabolism. 
Rizzello, F., DePaolis, A., Durante, M., Blando, F., Mita, G. \& Caretto, S. (2014): Enhanced production of bioactive isoprenoid compounds from cell suspension cultures of Artemisia annua L. using $\beta$-Cyclodextrins. Int. J. Mol. Sci., 15: 1909219105.

http://www.researchgate.net/publication/51077608_Plant_cell_cultures_bioreactors_for_i ndustrial_production, 2009.

Ryu D.D.Y. \& Furusaki S. (1994): Advances in Plant Biotechnology. Elsevier B.V. ISBN: 978-0-444-89939-2

Sanghera, G.S., Malhotra, P.K., Sidhu, G.S., Sharma, V.K., Sharma, B.B. \& Karan, R. (2013): Genetic engineering of crop plants for enhanced antioxidants activity. International Journal of Advancements in Research \& Technology, 2 (5).

Schijlen, E., de Vos, C.H.R., Jonker, H., van den Broeck, H., Molthoff, J., van Tunen, A., Martens S. \& Bovy, A. (2006): Pathway engineering for healthy phytochemicals leading to the production of novel flavonoids in tomato fruit. Plant Biotechnology Journal, 4: 433-444.

Schijlen, E.G.W.M., de Vos, C.H.R., Martens, S., Jonker, H.H., Rosin, F.M., Molthoff, J.W., Tikunov, Y.M., Angenent, G.C., van Tunen, A.J. \& Bovy, A.G. (2007): RNA interference silencing of chalcone synthase, the first step in the flavonoid biosynthesis pathway, leads to parthenocarpic tomato fruits. Plant Physiology, 144: $1520-1530$.

Siahpoush, A., Ghasemi, N., Ardakani, M.S. \& Asghari, G. (2011): Production of chlorogenic acid in Varthemia persica DC (var. persica) callus cultures. Res. Pharm. Sci., 6 (1): 63-69.

Shih, C.H., Chen, Y., Wang, M., Chu, I. K. \& Lo, C. (2008): Accumulation of isoflavonegenistin in transgenic tomato plants overexpressing a soybean isoflavone synthase gene. J. Agric. Food Chem., 56: 5655-5661.

Terahara, N., Callebaut, A., Ohba, R., Nagata, T., Ohnishi-Kameyama, M, \& Suzuki, M. (2001): Acylated anthocyanidin 3-sophoroside-5-glucosides from Ajuga reptans flowers and the corresponding cell cultures. Phytochemistry, 58: 493-500.

Trajtemberg, S.P., Apostolo, N.M. \& Fernadez, G. (2006): Calluses of Cynara cardunculus var. cardunculus cardoon (Asteraceae): determination of cynarine and chlorogenic acid by automated high-performance capillary electrophoresis. In Vitro Cell Dev. Biol. Plant, 42: 534-7.

Treutter, D. (2010): Managing Phenol Contents in Crop Plants by Phytochemical Farming and Breeding-Visions and Constraints. Int. J. Mol. Sci., 11: 807-857.

Valko, M., Leibfritz, D., Moncol, J., Cronin, M.T., Mazur, M. \& Telser, J. (2007): Free radicals and antioxidants in normal physiological functions and human disease. Int. J. Biochem. Cell Biol., 39 (1): 44-84.

Valko, M., Rhodes, C.J., Moncol, J., Izakovic, M. \& Mazur, M. (2006): Free radicals, metals and antioxidants in oxidative stress-induced cancer. Chemico-Biological Interactions, 160: 1-40.

Verhoeyen, M.E., Bovy, A., Collins, G., Muir, S., Robinson, S., de Vos, C.H.R. \& Colliver, S. (2002): Increasing antioxidant levels in tomatoes through modification of the flavonoid biosynthetic pathway. Journal of Experimental Botany, 53 (377): 2099-2106.

Ververidis, F., Trantas, E., Douglas, C., Vollmer, G., Kretzschmar, G. \& Panopoulos, N. (2007): Biotechnology of flavonoids and other phenyl-propanoid-derived natural products. Part I and part II, Biotechnol. J., 2: 1214-1234. 
Wroblewski, T., Tomczak, A. \& Michelmore, R. (2005): Optimization of Agrobacteriummediated transien tassays of gene expression in lettuce, tomato and Arabidopsis. Plant Biotechnology Journal, 3: 259-273.

Yeddes, N., Chérif, J.K., Guyot, S., Sotin, H. \& Ayadi, M.T. (2013): Comparative Study of antioxidant power, polyphenols, flavonoids and betacyanins of the peel and pulp of three Tunisian opuntia forms. Antioxidants, 2: 37-51.

Zhu, C., Sanahuja, G., Yuan, D., Farre, G., Arjo, G., Berman, J., Lopez, U.Z., Banakar, R., Bail, C., Perez-Massot, E., Bassie, L., Capell, T. \& Christou, P. (2013): Biofortification of plants with altered antioxidant content and composition: genetic engineering strategies. Plant biotechnology journal, 11: 129-141.

www.scielo.cl/scielo.php?pid=S0718-16202009000200001\&script=sci_arttext

www.scielo.cl/scielo.php?pid=S0718-16202009000200001\&script=sci_arttext 